\title{
Monitoring the Domestic Harvest of Migratory Birds in Nunatsiavut, Labrador
}

\author{
DAVID C. NATCHER, ${ }^{1}$ LARRY FELT, ${ }^{2}$ KEITH CHAULK,${ }^{3}$ ANDREA PROCTER ${ }^{4}$ \\ and THE NUNATSIAVUT GOVERNMENT ${ }^{5}$
}

(Received 19 October 2010; accepted in revised form 21 December 2010)

\begin{abstract}
The 2007 Nunatsiavut Inuit Migratory Bird Harvest Study found that the harvest of migratory birds by Nunatsiavut (Labrador) communities represents an important component of their overall subsistence harvest. During the 2006-07 year, the Nunatsiavut migratory bird harvest was a reported 5468 birds. Annual harvest estimates at the household, community, and regional levels are summarized. Although these data represent only a single harvesting year, the baseline information that has now been identified will contribute to the establishment of Inuit domestic harvest levels, thereby recognizing the legitimate harvesting needs of Inuit households, while helping to ensure the conservation of migratory bird populations into the future.
\end{abstract}

Key words: Nunatsiavut, migratory birds, subsistence, Labrador, wildlife policy, management

RÉSUMÉ. L'étude Nunatsiavut Inuit de 2007 portant sur les oiseaux migratoires a permis de constater que la récolte des oiseaux migrateurs par les collectivités du Nunatsiavut (Labrador) représente une composante importante de la récolte de subsistance générale de ces collectivités. Au cours de l'année 2006-2007, la récolte des oiseaux migratoires du Nunatsiavut s'est chiffrée à 5468 oiseaux. Cet article résume les récoltes estimées par domicile, par collectivité et par région. Bien que les données ne représentent qu'une seule année de récolte, l'information de base qui en a été tirée aidera à déterminer les taux de récolte domestiques des Inuits, ce qui permettra de faire ressortir les besoins légitimes en récolte des foyers inuits tout en favorisant la conservation des populations d'oiseaux migrateurs à l'avenir.

Mots clés : Nunatsiavut, oiseaux migrateurs, subsistance, Labrador, politique sur la faune, gestion

Traduit pour la revue Arctic par Nicole Giguère.

\section{INTRODUCTION}

On 1 December 2005, when the Labrador Inuit Land Claims Agreement Act came into effect, the Nunatsiavut Government took its place as a regional Inuit government within the province of Newfoundland and Labrador, with administrative authority over the departments of health, education, justice, culture, and language. In addition, it assumed responsibility for the protection, use, and development of renewable and nonrenewable resources in the Nunatsiavut settlement region. Through its Department of Lands and Natural Resources, the new government is now in charge of the "sustainable management of Nunatsiavut land and natural resources while maximizing benefits from the development of these resources for Inuit" (http://www.nunatsiavut. $\mathrm{com} /$ ).
A key component of the Department's mandate is to determine the Inuit Domestic Harvest Level (IDHL) for 140 different wildlife species and other natural resources that Inuit use to satisfy their nutritional, cultural, and ceremonial needs. Establishing IDHL is necessary in cases of concern about the conservation of wildlife populations, particularly migratory species. In such cases, Inuit harvesters retain the right to harvest up to the established IDHL. However, if no IDHL has been identified, responsibility for setting harvest limits for migratory species falls largely to the discretion of the federal government. Recognizing the need to establish IDHLs, the Nunatsiavut Government, with additional funding support from the Canadian Wildlife Service, commissioned research that would begin to identify the IDHL for 140 different resources and wildlife species. This list includes six species of migratory birds: Canada

\footnotetext{
${ }^{1}$ Corresponding author: College of Agriculture and Bioresources, University of Saskatchewan, 51 Campus Drive, Saskatoon, Saskatchewan S7N 5A8, Canada; david.natcher@usask.ca

2 Department of Sociology, Memorial University of Newfoundland, St. John's, Newfoundland and Labrador A1C 5S7, Canada; 1felt@mun.ca

${ }^{3}$ Labrador Institute of Memorial University, Happy Valley-Goose Bay, Newfoundland and Labrador A0P 1E0, Canada; keith.chaulk@mun.ca

${ }^{4}$ Department of Anthropology, Memorial University of Newfoundland, St. John's, Newfoundland and Labrador A1C 5S7, Canada; andrea.procter@mun.ca

525 Ikajuktauvik Road, PO Box 70, Nain, Newfoundland and Labrador A0P 1L0, Canada

(C) The Arctic Institute of North America
} 
goose (Branta canadensis), black duck (Anas rubripes), common eider (Somateria mollissima), surf scoter (Melanitta perspicillata), black scoter (Melanitta americana), and white-winged scoter (Melanitta deglandi). These six species are the most abundant and most extensively harvested by Inuit hunters. Inuit occasionally harvest other species of less abundant waterfowl with a more restricted distribution, but these are not generally used for subsistence purposes.

In this paper we present the results of the 2007 Nunatsiavut Migratory Bird Harvest Study. These include the estimated annual harvest of migratory birds by community and region, harvesting participation rates by community and species, and the seasonal concentration of waterfowl harvesting effort. These results, although representing only a single year, provide baseline information that for the first time will enable the Nunatsiavut Government and other wildlife management agencies to monitor community and regional harvesting levels. Such monitoring will contribute to better-informed wildlife management decisions in the future.

\section{METHODS}

Northern Labrador comprises a vast mosaic of wetlands, lakes, and rivers, including a vast archipelago of coastal islands. An important region for the staging and nesting of many migratory bird species, this area is especially important for breeding waterfowl of the Atlantic flyway (Chaulk et al., 2005). Nunatsiavut includes a $72500 \mathrm{~km}^{2}$ land base, as well as a $48690 \mathrm{~km}^{2}$ coastal zone that extends $800 \mathrm{~km}$ northward from Rigolet, the southernmost community in the Labrador Inuit Settlement Area (Fig. 1). Nunatsiavut is home to five predominantly Inuit communities-Rigolet, Makkovik, Postville, Hopedale, and Nain - and has a collective population of approximately 2764 residents, of whom 2511 identify themselves as Inuit. The communities of Nunatsiavut are evenly dispersed along the coast, and all share similar environmental characteristics: coastal barrens (Lopoukhine et al., 1977) located in a high-boreal ecoclimate (Meades, 1990) with a Low Arctic oceanographic regime (Nettleship and Evans, 1985).

In August 2007, 10 bilingual (English and Inuktitut) community research assistants were hired by the Nunatsiavut Government and underwent a multiday research training session. The training included important components of the research process: survey design; interview methods; data entry, analysis, and management; and report writing. After their training, the community research assistants tested the survey instrument with several key informants and made adjustments where necessary. The survey design, modeled on a research program in Alaska (Fall, 1990), used stand-alone, non-repetitive household surveys to identify baseline harvesting levels. Community research assistants administered the survey in the fall of 2007.

The approach uses a memory recall strategy in which harvesters are asked to recall the number of birds harvested

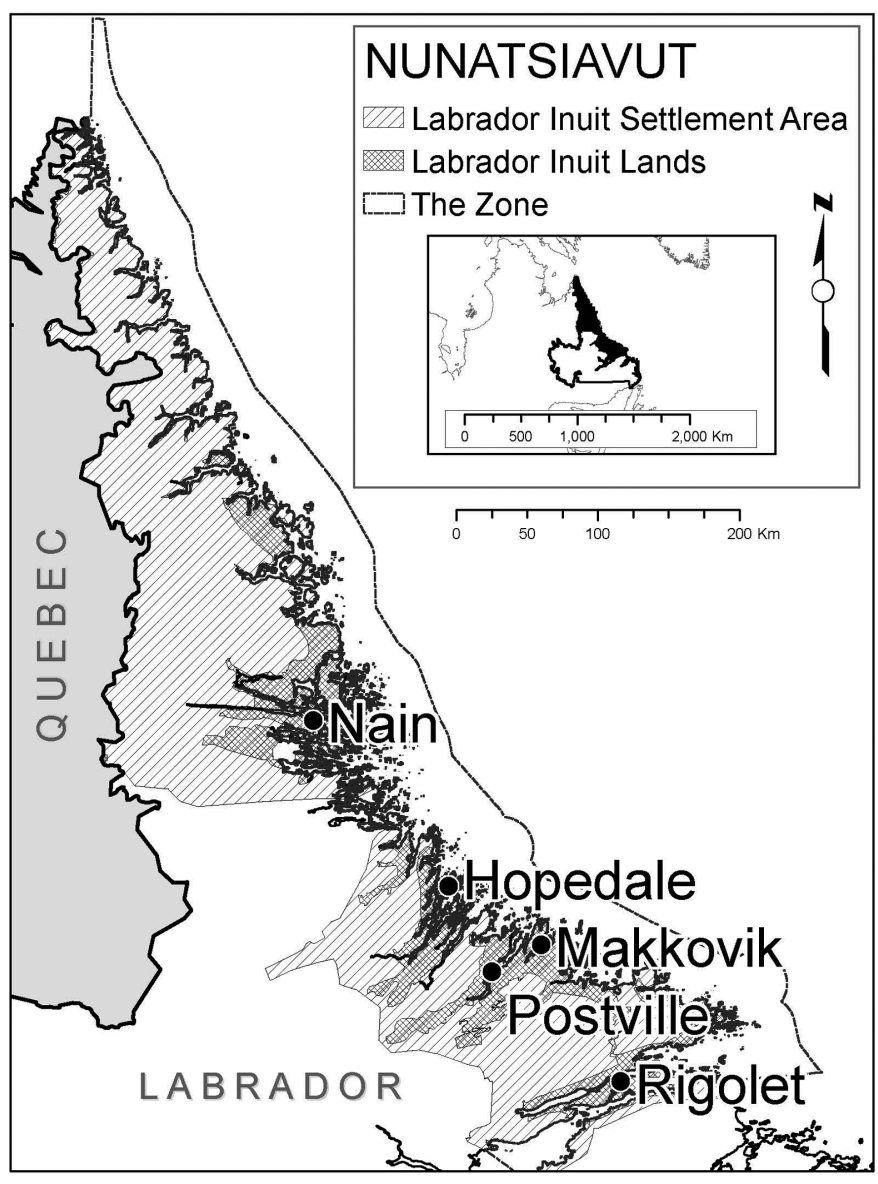

FIG. 1. The communities of Nunatsiavut, Labrador. Map created by Bryn Wood.

during the preceding year. To assist in recall and help avoid recall bias (Nelson et al., 2008), we divided the previous year (2006-07) into four time periods corresponding to local harvesting seasons. Coloured photographs of migratory bird species were provided, with species names listed in Inuktitut, English, and local nomenclature. Community research assistants recorded the household's total harvest over the preceding year, the seasonality of harvest, and household demographic information. Households were categorized according to five development stages defined by Magdanz et al. (2002): 1) Inactive single parent, retired elder, inactive single households (single grouping); 2) Developing households (with a head 20-39 years old); 3) Mature households (with a head 40-59 years old); 4) Active elder households (with a head age 60 or more and still actively harvesting); and 5) Active single person households.

Our objective was to achieve complete coverage of all Nunatsiavut households. The household was the primary unit of analysis, and the community, the secondary unit. Research assistants were instructed to interview the primary harvesters for each household. If more than one harvester was present, they tried to interview all harvesters. Up to three attempts were made to complete household interviews. Movement to and from communities, refusals, and 
TABLE 1. Reported and projected harvest of migratory birds by species and community, 2007.

\begin{tabular}{|c|c|c|c|c|c|c|c|c|c|c|c|c|}
\hline & \multicolumn{2}{|c|}{ Rigolet } & \multicolumn{2}{|c|}{ Makkovik } & \multicolumn{2}{|c|}{ Postville } & \multicolumn{2}{|c|}{ Hopedale } & \multicolumn{2}{|c|}{ Nain } & \multicolumn{2}{|c|}{ Total } \\
\hline & $\overline{\mathrm{RH}^{1}}$ & $\mathrm{PH}^{1}$ & RH & $\mathrm{PH}$ & RH & $\mathrm{PH}$ & RH & $\mathrm{PH}$ & RH & $\mathrm{PH}$ & $\mathrm{RH}$ & $\mathrm{PH}$ \\
\hline Canada goose & 187 & 246 & 189 & 240 & 148 & 187 & 184 & 214 & 390 & 450 & 1098 & 1337 \\
\hline Black duck & 266 & 350 & 169 & 215 & 211 & 267 & 199 & 231 & 220 & 254 & 1065 & 1317 \\
\hline Common eider & 312 & 411 & 446 & 567 & 235 & 297 & 780 & 907 & 369 & 426 & 2142 & 2608 \\
\hline Surf scoter & 248 & 327 & 27 & 34 & 101 & 128 & 188 & 219 & 32 & 37 & 596 & 745 \\
\hline Black scoter & 40 & 53 & 176 & 224 & 150 & 189 & 90 & 105 & 38 & 44 & 494 & 615 \\
\hline White-winged scoter & 0 & 0 & 4 & 5 & 16 & 20 & 27 & 31 & 26 & 30 & 73 & 86 \\
\hline Total & 1053 & 1387 & 1011 & 1285 & 861 & 1088 & 1468 & 1707 & 1075 & 1241 & 5468 & 6708 \\
\hline
\end{tabular}

${ }^{1} \mathrm{RH}=$ Reported Harvest and $\mathrm{PH}=$ Projected Harvest.

TABLE 2. Household harvesting participation rates by community and species, 2007.

\begin{tabular}{|c|c|c|c|c|c|c|c|c|c|c|}
\hline & \multicolumn{2}{|c|}{ Rigolet } & \multicolumn{2}{|c|}{ Makkovik } & \multicolumn{2}{|c|}{ Postville } & \multicolumn{2}{|c|}{ Hopedale } & \multicolumn{2}{|c|}{ Nain } \\
\hline & $\mathrm{N}$ & $\%$ & $\mathrm{~N}$ & $\%$ & $\mathrm{~N}$ & $\%$ & $\mathrm{~N}$ & $\%$ & $\mathrm{~N}$ & $\%$ \\
\hline Canada goose & 33 & 45 & 32 & 37 & 32 & 57 & 39 & 35 & 85 & 40 \\
\hline Black duck & 37 & 50 & 26 & 30 & 27 & 48 & 28 & 25 & 61 & 29 \\
\hline Common eider & 33 & 45 & 22 & 26 & 26 & 46 & 41 & 36 & 62 & 30 \\
\hline Surf scoter & 28 & 38 & 5 & 6 & 14 & 25 & 21 & 19 & 5 & 2 \\
\hline Black scoter & 1 & 1 & 17 & 20 & 20 & 36 & 10 & 9 & 10 & 5 \\
\hline White-winged scoter & 0 & 0 & 1 & 1 & 5 & 9 & 1 & 1 & 11 & 5 \\
\hline
\end{tabular}

difficulties in locating relevant household members affected the survey completion rate. In each community, $70-85 \%$ of households completed the survey. A total of 665 surveys were completed from 841 households, giving a mean overall completion rate, weighted by community size, of $80 \%$.

After the survey was completed, both the reported and projected harvests were calculated. The reported harvest represents the actual harvest reported, by species and by community. The projected harvest was derived from an extrapolation of non-surveyed households. For example, if the reported number of birds harvested for a given species was based on the $85 \%$ of community households that were surveyed, the reported harvest would be extrapolated by $15 \%$ to arrive at the projected harvest (Cochran, 1977). Such extrapolation assumes that the households not included in data collection do not differ substantially from those surveyed. Therefore, members of the research team asked the interviewers (all lifelong residents of their communities) and the local Nunatsiavut conservation officers about the harvesting patterns of those households not interviewed. In all cases, missing households were thought to be typical, and we assumed that these households did not represent outliers in terms of harvest effort or preference.

\section{RESULTS AND DISCUSSION}

During 2006-07, the Nunatsiavut migratory bird harvest was a reported 5468 birds and the total projected harvest, 6708. Annual estimates for the total and projected harvest of migratory birds at the community and regional levels are summarized in Table 1.

Common eiders represent $39 \%$ of the total harvest, followed by Canada geese (20\%) and black ducks (19\%). Inuit harvesting of migratory birds occurred throughout the year, but $75 \%(4101 / 5468)$ of the total harvest was concentrated in the fall. Spring accounted for 19\% (1039/5468 birds), and the remaining $6 \%(328 / 5468)$ of birds were harvested opportunistically in other seasons.

In terms of edible food weight (Stanek et al., 2007), the Nunatsiavut migratory bird harvest contributes roughly $3038 \mathrm{~kg}$ (1.10 kg per person) of food for Nunatsiavut households, with a storebought exchange value of approximately $\$ 29,620.00$ (frozen chicken at $\$ 9.75 \backslash \mathrm{kg}$ ). We offer four important contextual points. First, the conversion of edible foods weights is based on data derived by Stanek et al. (2007) for Cook Inlet, Alaska, so there may be some regional weight differences from species harvested in Labrador. Second, although the harvest of migratory birds provides only $3038 \mathrm{~kg}$ (1.10 kg per person) of food for Nunatsiavut households, it nevertheless represents an important seasonal component of Nunatsiavut's annual wild food harvest (Natcher, 2009). Third, given the difficulty of securing earned income in most, if not all, Nunatsiavut communities, a $\$ 29,620.00$ equivalent contribution towards household food consumption is not unimportant, particularly given its enhanced nutritional contribution. Fourth, our estimates of commercial food costs may be low, since food prices in the more northerly communities can easily double near the end of winter until northern stores are resupplied by summer supply barges. For these reasons, the harvest of migratory birds is an important subsistence activity for many Inuit households.

There is, however, some variation in harvesting participation rates among Nunatsiavut households. Table 2 shows the household harvesting participation rates by community and species. Canada goose, black duck, and common eider are the predominant species targeted by hunters of the five 
communities, attracting mean participation rates of $43 \%$, $36 \%$, and $37 \%$ respectively. Table 2 also reveals considerable variability around these mean values. For example, the participation range for Canada goose is from 57\% (Postville) to $35 \%$ (Hopedale), while those for the two other most targeted species are $25 \%$ (black duck) and 20\% (common eider). Specific birds are important to some but not all communities. For example, surf scoter has relatively high participation rates in the communities of Rigolet (38\%) and Postville (25\%), and black scoter has high participation in Postville (36\%). While all communities reflect a relatively high participation in bird harvesting, Rigolet and Postville suggest more extensive levels than the other Nunatsiavut communities.

Explaining harvest profiles across and between communities is complex. Like more general participation patterns, these profiles likely reflect a combination of humancentered factors (including cultural preferences, disposable income to acquire capital inputs for harvesting, and available time) and wider environmental and biological factors (such as community location, adjacency of suitable habitat, and bird abundance). Variability among harvesting households can also be explained in part by their varying stages of household development. For example, Mature households $(n=199)$, representing $30 \%$ of all Nunatsiavut households, harvested 3062 birds (15.4 birds per household), or $56 \%$ of the total harvest. They were followed by Developing households $(n=171)$, which accounted for $30 \%$ of the total harvest (1640 birds or 9.6 birds per household); Active Single households $(n=76)$, with $8 \%$ of the harvest (437 birds or 5.8 birds per household); Active Elder households $(\mathrm{n}=46)$, with $4 \%$ of the harvest (220 birds or 4.8 birds per household); and Single Parent/Inactive Elder households $(\mathrm{n}=73)$, which accounted for less than $2 \%$ of the total Nunatsiavut migratory bird harvest (109 birds or 1.5 birds per household). As Nunatsiavut households mature, their social configuration changes through normative cycles of development (Magdanz et al., 2002), which directly affect the household's ability to harvest migratory birds. For a period of time, Mature households have the means (i.e., labour, access to income, harvesting ability) to participate most extensively in harvesting activities, and therefore harvest the greatest number of birds, whereas Single Parent/ Inactive Elder households, which fall outside the normative development cycle, have limited capacity to engage in harvesting activities and therefore the smallest harvest.

Reasons cited for not harvesting migratory birds include physical disabilities or obstacles associated with old age (14\% of responses), prohibitive cost of equipment and gas (19\% of responses), time commitments related to wageearning employment and school (20\% of responses), and a general lack of interest in pursuing harvesting activities ( $47 \%$ of responses). While some members of all household types identified their lack of interest in harvesting wild foods, this factor was cited most often by community members between the ages of 15 to 24. Ford et al. (2008:57) have suggested that the lack of interest in harvesting wild foods can in time be countered by a reassertion of cultural values that often occurs as Inuit youth mature and assume the prominent role of provider for their families. This may be the case, but there are concerns that because many of the land-based skills required to be a successful harvester are learned at a young age, and refined through practice, those wanting to return to harvesting at a later stage of life may have limited opportunities to do so, not having acquired the necessary skills during their developmental stages of life (Natcher, 2009).

\section{CONCLUSION}

This research has successfully documented the importance of contemporary uses of migratory birds by Nunatsiavut communities. The baseline of information sensitive to community-level participation and harvest variability that has now been established will allow the Nunatsiavut Government to monitor and track changes in harvesting activities and bird population trends. In addition, although the Migratory Bird Treaty Act (1918) was amended in 1997 to legalize the spring and summer harvest of migratory birds by northern Aboriginal peoples of Canada and Alaska, the Nunatsiavut Government recognizes the need to monitor the spring migratory bird harvest to ensure that populations are not adversely affected by the spring hunt. The information being gathered through this research program will not only contribute to the establishment of Inuit Domestic Harvest Levels (thereby recognizing the legitimate harvesting needs of Inuit households), but also help ensure the protection of migratory birds populations into the future. Equally important has been the training of Inuit community researchers, which has been critical to ensure a transfer of analytical skills needed for Nunatsiavut to continue the research and monitoring program so that changes in IDHL can be tracked over time. Through these training efforts, a cadre of Nunatsiavut community-based researchers has been established that is now extending the research to other key IDHL species, as well as contributing to a wide range of other important research and wildlife conservation objectives.

\section{REFERENCES}

Chaulk, K., Robertson, G.J., Collins, B.T., Montevecchi, W.A., and Turner, B. 2005. Evidence of recent population increases in common eiders breeding in Labrador. Journal of Wildlife Management 69(2):805-809.

Cochran, W.G. 1977. Sampling techniques, 3rd ed. New York: John Wiley \& Sons.

Fall, J.A. 1990. The Division of Subsistence of the Alaska Department of Fish and Game: An overview of its research program and findings. Arctic Anthropology 27(2):68-92.

Ford, J.D., Smit, B., Wandel, J., Allurut, M., Shappa, K., Ittusarjuat, H., and Qrunnut, K. 2008. Climate change in the Arctic: Current and future vulnerability in two Inuit communities in Canada. The Geographical Journal 174(1):45-62. 
Lopoukhine, N., Prout, N.A., and Hirvonen, H.E. 1977. The ecological land classification of Labrador: A reconnaissance. Series 4. Ottawa: Environment Canada.

Magdanz, J.S., Utermohle, C.J., and Wolfe, R.J. 2002. The production and distribution of wild food in Wales and Deering, Alaska. Technical Paper 259. Juneau: Division of Subsistence, Alaska Department of Fish and Game.

Meades, S. 1990. Natural regions of Newfoundland and Labrador. St. John's: Protected Areas Association of Newfoundland and Labrador.

Natcher, D.C. 2009. Subsistence and the social economy of Canada's aboriginal North. The Northern Review 30:69-84.
Nelson, M., Natcher, D.C., and Hickey, C.G. 2008. Subsistence harvesting and the cultural sustainability of the Little Red River Cree Nation. In: Natcher, D.C., ed. Seeing beyond the trees: The social dimensions of aboriginal forest management. Concord, Ontario: Captus Press. 29-39.

Nettleship, D.N., and Evans, P.G.H. 1985. Distribution and status of Atlantic Alcidae. In: Nettleship, D.N., and Birkhead, T.R., eds. The Atlantic Alcidae. London: Academic Press. 53-154.

Stanek, R.T., Holen, D.L., and Wassillie, C. 2007. Harvest and uses of wild resources in Tyonek and Beluga, Alaska, 2005-2006. Technical Paper 321. Juneau: Division of Subsistence, Alaska Department of Fish and Game. 